\title{
"... gondjaink tesznek minket bátrakká ... "1 \\ Időszaki kiadványok elektronikus naplózása az ELTE Egyetemi Könyvtárban
}

\section{A könyvtári munkafolyamatok változásai}

Az elmúlt évekre (évtizedekre) és napjainkra is egyaránt jellemző, hogy egyre több könyvtári szolgáltatás válik részben vagy egészében elektronikussá, és egyre nagyobb számban jönnek létre digitális vagy digitális születésű dokumentumokra épülő könyvtári szolgáltatások. Közös jellemzőjük, hogy erőteljes felhasználói igény vagy informatikai vívmány hívja életre öket. Részletesen tájékozódhatunk ezekről a szolgáltatásokról akkor is, ha intézményünkben még nem kerültek bevezetésre, hiszen a könyvtári szaksajtó nagy hangsúlyt helyez ismertetésükre, elemzésükre. A változásokkal párhuzamosan a minőségi könyvtári szolgáltatás stabil alapját képező feldolgozói munkafolyamatokban is megjelent az igény a digitális környezet kihívásainak való megfelelésre. A tanulmány célja egy ilyen folyamat bemutatása, melynek során az időszaki kiadványok hagyományos, papíralapú naplózása lezárult, és felváltotta az elektronikus napló készítése.

\section{Időszaki kiadványok állományba vétele}

Az időszaki kiadványok állományba vételét külön rendelet nem szabályozza, a 3/1975-ös KM-PM együttes rendeletben² leírtak tekintendők kötelező érvényünek, ami azonban nagy vonalakban csak annyit követel, hogy a nem átmeneti idöszakra (3 év) beszerzett dokumentumokról állománynyilvántartást kell vezetni.

„2. § (1) A könyvtár köteles minden dokumentumáról - a számvitel rendjéröl szóló 1968. évi 33. törvényerejü rendelet 3. és 6. \$-aiban foglalt rendelkezésekkel összhangban - folyamatosan és idösorrendben olyan állománynyilvántartást (leltárt) vezetni, amelynek alapján az állomány

${ }^{1}$ Peck, Morgan Scott A járatlan út. Budapest, Park Kiadó, 2014. Borító.

2 3/1975. (VIII. 17.) KM-PM együttes rendelet A könyvtári állomány ellenőrzéséről (leltározásáról) és az állományból történő törlésről szóló szabályzat kiadásáról (hatálybalépés: 1978. augusztus 17.) Forrás: http://net.jogtar.hu/jr/gen/hjegy_doc.cgi?docid=[-] 97500003.KMA [2015.07 20.] 
egészének a darabszáma és értéke, továbbá az egyes dokumentumok értéke bármikor megállapítható és ellenörizhetö." 3

A rendeletben hivatkozott 1968. évi 33. törvényerejü rendelet ${ }^{4}$ hatályát vesztette, helyette a 2000. évi C. törvény ${ }^{5}$ rendelkezései kötelezök. A könyvtári dokumentumok állománynyilvántartásáról az MSZ 3448-786 szabvány is rendelkezik, mely az időszaki kiadványok tekintetében kimondja: ,,3.6.2. Az időszaki kiadványok teljes évfolyamait illetve köteteit egyedi vagy összesitett állománynyilvántartásba kell venni. "7 Ebben a formában a szabvány több szempontból nehezíti az időszaki kiadványait köttető könyvtárak gyakorlatát. Például évkönyvek esetében az állományba vételnek kötetenként kell történnie. Ha több évkönyv kerül ugyanabba a kötési egységbe, kialakul az a speciális helyzet, hogy egy darab fizikai egység több egyedi leltárszámot tartalmaz.

Az időszaki kiadvány, mint speciális könyvtári dokumentum kezeléséről rendelkezö, és azt részletezö törvényi szabályozás hiányában eltérö szokások alakultak ki a periodikák naplózását illetően. Gyakori az évfolyam alapú naplózás, de arra is bőven van példa, hogy teljességgel hiányzik, illetve estleges a nyilvántartásba vételük. Ez utóbbi föként akkor fordul elö, ha egy könyvtár az évkönyvet könyv dokumentumként értelmezi, és mint ilyen, bekerül a könyvekről vezetett állománynaplóba. Ugyanakkor az újságok, folyóiratok naplózása elmarad. Sok helyen pedig a cardex lap tölti be a végleges állománynyilvántartás funkciót is.

\section{Az Egyetemi Könyvtár állománya, naplózási gyakorlata}

Az Egyetemi Könyvtár periodika állományának kezelése kiemelt helyet foglal el a gyüjtemény gondozásában, hiszen annak jelentős részét képezi a mintegy 250000 bekötött egység, amely megközelítően 15000 címet foglal magában, és az elmúlt évekre jellemző csökkenő tendencia ellenére is évente 700-900 kurrens cím érkezik be.

${ }^{3}$ I. m. I. fejezet Általános rendelkezések.

${ }^{4}$ 1968. évi 33. tvr. a számvitel rendjéről (XII. 7.) (hatálybalépés: 1969. január 1.). = Pénzügyi Közlöny, 1968, 35. sz. (dec. 17.) 737-740. p.

52000 . évi C. törvény A számvitelről (hatálybalépés: 2001. január 1.). Forrás: http://[-] net.jogtar.hu/jr/gen/hjegy_doc.cgi?docid=A0000100.TV [2015. 07. 20.]

${ }^{6}$ MSZ 3448-78 A könyvtári állomány nyilvántartása (hatálybalépés: 1980. január 1.). Budapest, MSZH, [1978.] 4 p.

${ }^{7}$ I. m. 3. Állománynyilvántartás. 
Az állomány naplózásának története régmúltra tekint vissza. A papíralapú naplózás 1953-ban indult, 22 évvel megelőzve a 3/1975-ös rendelet megjelenését. (Az azóta keletkezett leltárkönyvek több polcot is megtöltöttek, és mennyiségük folyóméterben is jól kifejezhetővé vált.) A Horizon integrált könyvtári rendszerben 2000 végétől valósult meg a hibrid naplózás (elektronikusan felvett adatokból papíralapú napló nyomtatása), amely korunk talán legelterjedtebb állománynyilvántartási gyakorlata, majd 2011-ben erősödött fel a kizárólag elektronikus napló készítésének igénye az Aleph integrált könyvtári rendszerre történő váltásnak köszönhetően. A szándék már korábban megfogalmazódott a párhuzamos, többszörös nyilvántartás csökkentésének igényével együtt. A legfontosabb érvek az alábbiak voltak: digitális környezetben a papíralapú dokumentumok hatékonysága megkérdőjelezhető, az erőforrás-optimalizáló és hozzáférhetőséget biztosító követelményeknek való megfelelés valamint a költségvetési megszorításokból adódó költségcsökkentő intézkedések.

Az Egyetemi Könyvtárban a naplózás alapja az évfolyam, évkönyvek esetében a kötet volt 2011-ig (bár található példa eltérésekre is, különösen visszamenőleges állományba vétel esetén), a naplózás esedékessége pedig az utolsó szám beérkezése. 2011-re határozott igény alakult ki a gyakorlat-alapú, olvasó/kölcsönzésbarát megoldásra, ezért a korábbi gyakorlatot módosítanunk kellett. Vizsgálva a könyves módszert, a naplózás új alapja a kötési egység lett, melynek indoka, hogy ha bármilyen esemény történik (például átirányítás, előjegyzés, kölcsönzés, könyvtárközi kérés, eltulajdonítás), az mindig a kötési egységgel történik, és nem feltétlenül az évfolyammal. Az évfolyam csak szerencsés esetekben tud egyetlen kötési egységbe kerülni, gyakoribb példa az, ha a teljes évfolyam több kötési egységet alkot, illetve egy kötési egység több évfolyamot is tartalmaz. A naplózás esedékessége továbbra is az utolsó tag beérkezésének időpontja maradt, hiszen így a legnagyobb az adatbiztonság, és az új módszerrel a naplózási és kötési elv is összhangba került. 


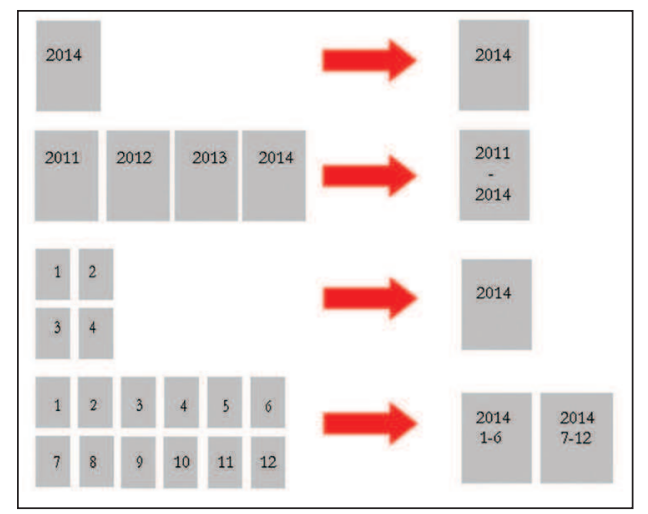

1. ábra. Általános kötési elv időszaki kiadványok esetében

Ahhoz, hogy az új naplózási elv az Aleph-ben is alkalmazható legyen, meg kellett vizsgálni a példányadat-kezelés lehetőségeit, a technikai megoldásokat, valamint a példányadatokba bekerülő e-adatokra építhető szerviz és lekérdező funkciókat. Abban az esetben, ha egy periodika önállóan kerül, vagy nem kerül köttetésre (tehát egy füzetszám, kötet egy kötési egység lesz), minden, a naplózásához szükséges adat felvételre kerül a saját, egyedi példányadatába. Akkor azonban, ha több évfolyamot kell megvárni a köttetéssel, illetve egy évfolyamból több kötési egység is keletkezik (vagyis egyetlen kötési egységhez több egyedi példányadat tartozik), létrehozásra kerül egy speciális példányadat-típus, a „periodika leltári példány". Ez az adat az olvasó számára nem látható, köttetésig az egyedi példányadatokkal párhuzamosan létezik, köttetés után azonban (az egyedi példányadatok törlésével) valódi példányadattá válik.

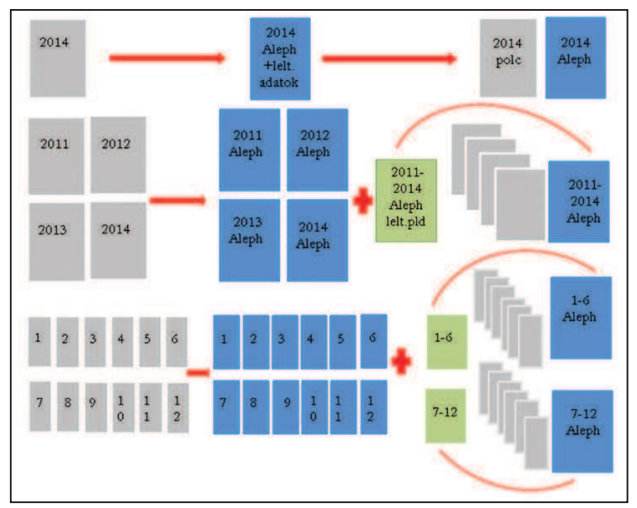

2. ábra. Időszaki kiadványok példányadatainak kezelési elve az Aleph integrált könyvtári rendszerben 
A periodika leltári példányadat tartalmazza a kötési egység egyedi információit: az egyedi azonosítókat (vonalkód, leltári szám, jelzet), a befoglaló tagok számozási adatait, az egyedi jellemzőket (például hiányok, kötési megjegyzések), a leltározáshoz szükséges adatokat (leltári szám, dátum, ár, beszerzés forrása, szállító), az elérhetőségre, szolgáltatásra vonatkozó információkat (például korlátozottan kölcsönözhető), a tagdokumentumok speciális, egyedi jellemzőit (például mellékletek, részcímek, tematikus címek).

\section{Az elektronikus leltárnapló}

A periodika leltári példányadatok, valamint a leltári adatot tartalmazó egyedi példányok adataiból a „Példányok-Inventory List” szerviz funkcióval könnyen összeállítható adott idöszak gyarapodási naplója. Egy elektronikus ürlap kitöltésével megadhatók a speciális feltételek, melyek alapján a program végrehajtja az adatbázis lekérdezését. A végeredményként kapott elektronikus lista a gyarapodási napló alapja. A ,riportoszlopok” tartalma, sorrendje lelőhelyenként személyre szabható, az adatforrások köre lehet a bibliográfiai rekord, példányadat és a szerzeményi modul is.

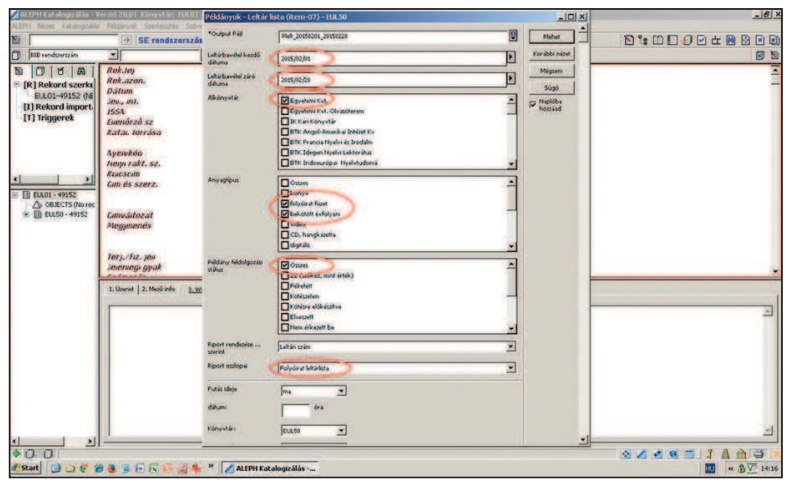

3. ábra. Elektronikus napló készítése szerviz funkció segítségével az Aleph integrált könyvtári rendszerben

Az Egyetemi Könyvtárban a periodika e-gyarapodási napló egy közös Excel-fájlba kerül átmentésre, így az összes dokumentumtípus, a teljes dokumentumállomány gyarapodási nyilvántartása egy helyen érhető el és férhető hozzá. Az adatvédelem az átmentést, ellenőrzést és jóváhagyást követően az oszlopok írásvédettségével biztosítható, így az adatok a továbbiakban nem felülírhatók. Egyetlen módosítható oszlop a „Megjegyzés" marad, ide kerülnek be az utólag felvett információk, a papíralapú naplózás gyakorlatával megegyezően. 
Az e-napló előnyei és hátrányai megegyeznek az elektronikus dokumentumokéval, legfontosabb jellemzői: tartalmazza az összes kötelező és szükséges információt, archiválható, megosztható, távolról elérhető, gyors visszakereshetőséget biztosít az adattartalomban, támogatja a statisztikai adatszolgáltatást és a statisztikai trend kimutatását, környezetbarát, helytakarékos. Az e-naplóval kapcsolatban sokáig megoldandó probléma volt a hitelesítés módja, melyre kielégítő megoldást kínál az integrált könyvtári rendszer által rögzített riport a példányadatok létrehozásáról, módosításáról.

A leltárnapló egyben pénzügyi okmány is, ezért a 3/1975-ös KM-PM együttes rendeleten kívül a számvitel rendjéről szóló jogszabály rendelkezései is vonatkoznak rá. Utóbbit hatályba lépése óta többször aktualizálták, legújabb, módosított verziója 2016. január 1-én lépett életbe. Az elektronikus leltárnapló formai és tartalmi tulajdonságainak a jogszabályoknak történő megfeleltetése összetett feladat volt. A felülvizsgálat eredményeképpen nem maradt olyan kitétel, melynek az új módszer ellentmondana. Előfordulnak azonban olyan, jelenleg még hatályban lévő jogszabályi követelmények, amelyeknek részben felel meg, bár ezen kritériumok esetében megfontolandó lenne szakmai indokoltságuk újragondolása.

Az állománynyilvántartásra vonatkozó kötelező elöírások:

- Minden dokumentumról folyamatosan, idösorrendben állománynyilvántartást vezet. Az e-napló ennek a szempontnak csak részben tud megfelelni, csakúgy, mint a papíralapú napló, hiszen nem a periodika füzetszámainak folyamatos, idősorrendben történő jegyzésére hivatott, hanem a leltári egységére. Az időszaki kiadvány füzeteinek, számainak, köteteinek beérkezésére, az időpont rögzítésére az MSZ 3448-78 szabványban is megengedett előzetes nyilvántartás szolgál.

- Megállapitható az állomány egészének darabszáma és értéke. Az e-napló alkalmas mindezen adat gyors és hatékony szolgáltatására.

- Megállapitható és ellenörizhetö az egyes dokumentumok értéke. Az e-napló alapján az egyes dokumentumok értéke bármikor megállapítható.

- Tartalmazza a dokumentum egyedi azonositásához szükséges és kötelezö adatokat. Az e-napló minden, az egyedi azonosításhoz elöírt, kötelező adatot tartalmaz.

- Tájékoztat a dokumentumok beszerzésének idejéröl és módjáról. Az e-napló ennek a feltételnek csak részben tud megfelelni (ahogy a papíralapú napló is), hiszen minden esetben tájékoztat a dokumentum 
beszerzésének módjáról, azonban az időszaki kiadványokhoz nem rendelhető egyetlen dátum, mint a beszerzés időpontja. Az időszaki kiadvány speciális dokumentum, mely egymást követő részegységekből áll. Kurrens állomány esetén (az évkönyv típusú periodikák kivételével) nem beszélhetünk egyetlen beérkezési/beszerzési időről, ilyen típusú információ csak a leltári egységbe tartozó részegységekhez rendelhetö, melyről az MSZ 3448-78 szabványban is megengedett elözetes nyilvántartás tájékoztat.

- Feltünteti a dokumentumok beszerzési árát, illetöleg a becsértékét. Az e-napló tartalmazza az árra vonatkozó információkat.

- Tartalmazza a dokumentum állományból törlésére vonatkozó utalást. A papíralapú leltárkönyv gyakorlatával megegyező módon, az utólag is módosítható megjegyzés oszlopnak köszönhetően az állományból törlésre vonatkozó utalások feljegyezhetők az e-naplóban is.

A pénzügyi okmányra vonatkozó kötelező elöírások:

- Folyamatosan számozott lapokból áll. Ez a kitétel nem feltétlenül indokolt írásvédelemmel ellátott elektronikus nyilvántartás és folyamatos leltári számsor esetében.

- Használatbavétel elött hitelesíteni kell. A kritérium teljesítésében nagy segítséget jelent a 2001. évi XXXV. törvény az elektronikus aláírásról. ${ }^{8}$

- Csak tollal vezethető. Ez a feltétel nem alkalmazható elektronikus nyilvántartás esetén.

- Téves bejegyzést egyszeri áthúzással és aláirással hitelesitett módon lehet javitani. Téves bejegyzések és a bejegyzöre vonatkozó információk felvételére a papíralapú leltárkönyv gyakorlatával megegyező módon, az utólag is módosítható megjegyzés oszlop szolgál.

- Nem selejtezhető. Az e-napló hosszú távú, megbízható tárolása egy arra alkalmas tárhely biztosításával megoldható.

2011-ben az Egyetemi Könyvtárban kialakult egy speciális helyzet, melynek eredményeképpen megszületett a döntés, hogy alkalmazkodva a digitális környezet és a megváltozott felhasználói szokások kihívásaihoz, az időszaki kiadványokról a továbbiakban elektronikus állománynyilvántartást vezetünk. Bátor döntés volt. Habár a gondjaink tettek minket bátrakká.

${ }^{8}$ 2001. évi XXXV. törvény az elektronikus aláírásról (kihirdetve 2001. június 12.). Forrás: http://net.jogtar.hu/jr/gen/hjegy_doc.cgi?docid=A0100035.TV [2015. 07. 20.] 


\title{
Rezümé
}

A tanulmány azt a folyamatot mutatja be, hogy mi indokolta és hogyan történt a hagyományos, papíralapú állományba vétel leváltása az elektronikus napló készítésére egy speciális dokumentumtípus, az időszaki kiadványok esetében az ELTE Egyetemi Könyvtárban. Megvizsgálja azokat a problémákat, melyek megoldása nélkül nem lett volna végrehajtható az áttérés. Bemutatja az állományba vétel elvének újragondolását, az elv összehangolását az integrált könyvtári rendszer által biztosított lehetőségekkel, valamint az elektronikus napló formai és tartalmi követelményeinek megfeleltetését a vonatkozó jogszabályoknak.

\section{Electronic inventory of periodicals in the University Library of ELTE}

The presentation shows the process, why and how the University Library of Eötvös Loránd University replaced the traditional paper-based inventory by creating electronic inventory in the case of a special type of document, the periodicals. It examines the problems that had to be solved in order to fulfill the change. It also explores the reconsideration process of inventorizing, the synchronization of the new principle with the integrated library system and the harmonization of requirements in terms of form and content of electronic inventory books with the relating law.

\author{
SZÉPVÖLGYI KATALIN \\ könyvtáros \\ ELTE Egyetemi Könyvtár
}

